\title{
The Relationship Between Emotional Intelligence and Diabetes Management: A Systematic Review
}

\author{
Aida Pérez-Fernández ${ }^{1}$, Pablo Fernández-Berrocal ${ }^{1}$ and María José Gutiérrez-Cobo ${ }^{2 *}$ \\ ${ }^{1}$ Department of Basic Psychology, Faculty of Psychology, University of Málaga, Málaga, Spain, ${ }^{2}$ Department of \\ Developmental and Educational Psychology, Faculty of Psychology, University of Málaga, Málaga, Spain
}

OPEN ACCESS

Edited by:

Giacomo Mancini,

University of Bologna, Italy

Reviewed by:

Jose Maria De La Roca-Chiapas, University of Guanajuato, Mexico Jose Miguel Mestre

University of Cádiz, Spain

*Correspondence:

María José Gutiérrez-Cobo mjgc@uma.es

Specialty section:

This article was submitted to Health Psychology,

a section of the journal

Frontiers in Psychology

Received: 30 August 2021 Accepted: 13 October 2021 Published: 04 November 2021

Citation:

Pérez-Fernández $A$ Fernández-Berrocal $P$ and Gutiérrez-Cobo MJ (2021) The Relationship Between Emotional Intelligence and Diabetes Management: A Systematic Review.

Front. Psychol. 12:754362. doi: 10.3389/fpsyg.2021.754362
Diabetes has been associated with affective disorders which complicate the management of the disease. Emotional intelligence (EI), or the ability to perceive, facilitate, understand, and regulate emotions, has shown to be a protective factor of emotional disorders in general population. The main objective of this study was to systematically review the role of the El construct in Type 1 and Type 2 diabetics and to observe how El is related to biological and psychological variables. Comprehensive searches were conducted in PubMed, Scopus, Psyclnfo, and Cochrane without time limitations, for studies examining the link between diabetes and El. A total of 12 eligible studies were selected according to the inclusion criteria. We divided the results into four sections: (1) El and hemoglobin glycosylated ( $\mathrm{HbA1c})$, (2) El training effects, (3) differences in El between persons with diabetes and without diabetes, and (4) El and psychological adjustment and well-being. The results showed negative correlations between $\mathrm{El}$ and $\mathrm{HbA} 1 \mathrm{c}$, positive effects of $\mathrm{El}$ training on quality of life, anxiety, and glycemic control, no differences in El between people with diabetes and healthy individuals, and, finally, negative correlations between El and different psychological variables such as diabetes-related anxiety and distress, and positive correlations with quality of life, well-being, and marital satisfaction. This systematic review offers a starting point for a theoretical and practical understanding of the role played by $\mathrm{El}$ in the management of diabetes and reveals that $\mathrm{El}$ is a promising protective factor for biological and psychological variables in this population.

Keywords: emotional intelligence, Type 1 diabetes, Type 2 diabetes, HbA1c, diabetes management, systematic review

\section{INTRODUCTION}

Diabetes mellitus is a chronic disease associated with significant morbidity and mortality throughout the world (Wild et al., 2004). The global prevalence of diabetes in 2019 is estimated to be $9.3 \%$ (463 million people), which may increase to $10.2 \%$ ( 578 million) by 2030 and $10.9 \%$ (700 million) by 2045 (Saeedi et al., 2019). Diabetes is a condition in which the body does not properly metabolize glucose. Two types of diabetes can be distinguished: Type 1 or insulin-dependent diabetes and Type 2 diabetes. For Type 1 diabetes, the causes are still unknown, it is a chronic disease, and its onset has a higher incidence in young people and children. Type 2 diabetes is triggered by excess body weight and physical inactivity, and onset 
is usually in adulthood. People with Type 1 diabetes need insulin, while those with Type 2 diabetes can be treated with oral medications, exercise, and diet (WHO, 2020). Over time, high glucose levels can lead to severe consequences, such as stroke, heart attacks, blindness, and kidney failure. The primary purpose of diabetes care should be to keep glucose levels within healthy limits. The daily behaviors aimed at maintaining healthy glucose levels and preventing the severe consequences of the disease (especially in Type 1 diabetes), and all make this condition highly stressful. This routine puts people with diabetes at a higher risk of psychological problems (Musselman et al., 2003; Egede, 2004; Goldney et al., 2004). In turn, it has been observed that alterations in glucose variability in diabetics have an impact on mood (Gonder-Frederick et al., 1989; Hermanns et al., 2003). Additionally, several studies analyzing the neuropsychobiological mechanisms underlying this relationship have found that the increase in hormones related to depression and stress (Sapolsky et al., 2000; Goodnick, 2001) also increases glucose levels.

Specifically, diabetes is associated with an increased risk of affective disorders in the adult population (Hislop et al., 2008; Gendelman et al., 2009). The relationship between diabetes and problems such as anxiety, depression, and anguish related to diabetes is attracting more attention due to its high prevalence (Anderson et al., 2001; Grigsby et al., 2002; Nicolucci et al., 2013) and its negative effect on self-care, glycemic control, and risk of complications and mortality (Collins et al., 2009; Park et al., 2013; Smith et al., 2013). Importantly, these disorders are associated with fewer self-care behaviors, poorer clinical outcomes, lower quality of life, and more severe and earlier onset of diabetes (Peyrot et al., 1999; Sipkoff, 2005; Gendelman et al., 2009; Lin et al., 2010). Consequently, psychology plays an essential role in the management of this disease, particularly when dealing with the practical problems and day-to-day diabetes routine. Due to this, it would be of interest to look for protective factors for population with diabetes that favor better control of the disease. One factor that researchers have recently been paying attention to is the emotional intelligence (EI) ability. Mayer and Salovey (1997) have defined this construct as:

The ability to perceive accurately, appraise, and express emotion; the ability to access and generate feelings when they facilitate thought; the ability to understand emotion and emotional knowledge; and regulate emotions to promote emotional and intellectual growth (p. 10).

Emotional intelligence has been conceptualized into three models depending on the measurement instrument used and the conceptualization of the construct: performance-based ability model, self-report ability models, and self-report mixed models (Joseph and Newman, 2010). The performance-based ability models evaluate EI through performance tests in an objective manner and conceive EI as a set of emotional skills based on the definition of Mayer and Salovey (1997). These models have greater empirical support (Mayer et al., 2016) than the other models. The self-report ability models are also based on these authors' conceptualization, although they use subjective selfreport measures. Finally, although they use self-report instruments, the self-report mixed models include a broader number of variables to define EI, such as mental abilities, personality factors, motivations, interpersonal and intrapersonal skills, and other facets (Bar-On, 2004). It is crucial to consider the model employed as the previous literature suggests there are weak correlations among them, suggesting that the models do not cover the same construct (Goldenberg et al., 2006).

The existing literature has shown that people with higher EI scores are more readily able to cope with stressors and problems in daily life, have closer relationships, and more significant social support networks (Zeidner et al., 2012). Consequently, EI is perceived as an indicator of psychological adjustment and is associated with well-being (Sánchez-Álvarez et al., 2016), happiness, and life satisfaction (Zeidner et al., 2012). In addition, there are also other reasons for proposing the hypothesis that EI is a critical element of diabetes. A higher EI level has been linked to healthier behaviors (FernándezAbascal and Martín-Díaz, 2015), better health (Mikolajczak et al., 2015), along with fewer negative emotions such as anxiety (Killgore et al., 2016), depression (Fernández-Berrocal and Extremera, 2016), or distress in the face of adversity (Armstrong et al., 2011). In clinical populations, the level of EI is lower among people with inflammatory disease (such as rheumatoid arthritis, ankylosing spondylitis, or multiple sclerosis) compared to the healthy population (Costa et al., 2014).

\section{Rationale}

Considering the previous literature, the primary purpose of this study is to systematically review the role of the EI construct in people with Type 1 and Type 2 diabetes by observing how EI is related to both biological and psychological variables in this population. We hypothesized that higher levels of EI would be a protective factor of diabetes management, as shown by better glycemic control and higher levels of psychological adjustment and well-being.

\section{MATERIALS AND METHODS}

\section{Literature Search}

PubMed, Scopus, PsycInfo, and Cochrane databases were searched exhaustively, without time limitations, for studies examining the link between diabetes and emotional intelligence. Searches were conducted using the following keywords in English: "Diabetes" combined with "emotional intelligence" as terms in the title or abstract. The searches were undertaken between September 2020 and September 2021.

\section{Inclusion Criteria}

To be included in the review, papers had to meet the following criteria: (1) empirical research providing data on the relationship between EI with any biological or psychological variable related to diabetes, (2) a sample with a Type 1 or Type 2 diabetes diagnosis, (3) a sample of any ethnicity, gender, or age (4) use of a valid and reliable emotional intelligence scale, and (5) articles written in Spanish or English. 


\section{Exclusion Criteria}

Letters, theses, comments, editorials, reports, or book chapters on previously published studies, intervention protocols, qualitative studies, and non-English or non-Spanish language publications were excluded.

\section{Data Extraction}

The initial database search identified 78 potentially eligible studies: 33 from Scopus, 15 from PubMed, 12 from Cochrane, and 18 from PsycInfo. After removing duplicates, this resulted in 59 studies. Two reviewers independently assessed the titles and abstracts of all of the reports identified. Of these 59 studies, only 20 were selected for full text review after considering the inclusion/exclusion criteria specified, and 12 studies were finally included. Disagreements were resolved by discussion with the senior reviewer. The process of finding and selecting the items is shown in Figure 1. In order to analyze the quality of the studies, we have included a table of quality assessment using the Mixed Methods Appraisal Tool (MMAT; Hong et al., 2018; Table 1).

\section{EI Instruments}

We next define the instruments used to measure EI in the studies selected.

I. The audiovisual emotional intelligence test (AVEI; Zysberg et al., 2011). This questionnaire belongs to the performancebased ability model of EI and measures the ability to perceive emotions. Twenty-seven audiovisual items are presented to the respondents (half are video clips and the other half images), and the participants must identify the emotion experienced by people portrayed in various personal and interpersonal settings. The total score measures correct responses, so a high score represents a higher level of EI. The reliability of the test has been shown to be acceptable (ranging from 0.67 to 0.78 in various settings).

II. The Emotional Processing subscale of the Emotional Approach Coping Scale (Stanton et al., 2000) belongs to the self-report ability models of EI. The scale consists of four items that are scored on a Likert scale that ranges from 1 (never) to 5 (always). It measures how the respondents recognize, accept, and understand their own emotions. The internal consistency and test-retest reliability of the scale were $\alpha=0.72$.

III. The Schutte Self-Report Emotional Intelligence Test (SEIS; Schutte et al., 1998) belongs to the self-report ability models of EI. This consists of 33 items that are scored on a Likert-type scale that ranges from 1 (strongly agree) to 5 (strongly disagree) in which respondents indicate their level of agreement with various statements on aspects of EI. It includes four subscales: emotion perception, utilizing emotions, managing self-relevant emotions, and managing others' emotions. The scale presents a high reliability of 0.90 .

IV. The Trait Meta Mood Scale (TMMS; Salovey et al., 1995) belongs to the self-report ability models of EI. It includes 30 -items on a Likert scale ranging from 0 to 4 (from "totally disagree" to "totally agree") and evaluates a total of three dimensions: "Attention" to emotions, which refers to people's belief in how much they attend to their feelings; "clarity" of emotions that measures how a person thinks that they perceive emotions, and, finally, emotional "repair" which evaluates a person's efforts to maintain positive emotions and block negative moods. Internal reliability for all three factors ranges from $\alpha=0.62$ to 0.87 .

V. The short version of EI-DARL (Antinienè and Lekavičienè, 2014). This belongs to the self-report ability models of EI. It consists of 73 questions in which respondents must report their agreement or disagreement on a 6-point Likert scale. This scale evaluates a total of five dimensions: "Understanding your emotions," "Your emotional control," "Understanding emotions of the other person," "Control of other emotions," and "Manipulations." The internal consistency was $\alpha=0.92$ (Žilinskiene et al., 2021).

VI. BarOn Emotional Quotient Inventory (EQ-I; Bar-On, 2004, 2006). This belongs to the self-report mixed models of EI. It includes 133 items with a Likert response scale of 1-5 (ranging from very rarely or not true for me to very often true for me or true for me). The scale provides an estimate of emotional and social intelligence. It is made up of five composite scales and 15 subscales: intrapersonal scales (self-regard, emotional self-awareness, assertiveness, independence, self-esteem), interpersonal scales (empathy, social responsibility, interpersonal relationships), adaptability scales (reality tests, flexibility, problem-solving), stress management scales (stress tolerance, impulse control), and general scales of the state of mood (optimism, happiness). EQ-I has proven to be a consistent, stable, and reliable measure. Its overall internal consistency is $\alpha=0.97$.

VII. The Shrink emotional intelligence questionnaire (Moradi et al., 2020). This belongs to self-report mixed models of EI. It consists of 33 items divided into five subscales (selfmotivation, self-awareness, self-management, coherence, and social skills). Its reliability coefficient was as follows: selfmotivation $=54 \%, \quad$ self-awareness $=69 \%, \quad$ selfmanagement $=64 \%$, coherence ( social intelligence $)=51 \%$, social skills $=50 \%$, and the global score $=85 \%$.

VIII. The profile of emotional competence (PEC; Brasseur et al., 2013) belongs to the self-report mixed models of EI. The questionnaire comprises 50 items scored on a 1-5 scale (ranging from strongly disagree to strongly agree). The final result offers three global scores: an intrapersonal EC score $(\alpha=0.86)$ and interpersonal EC score $(\alpha=0.89)$ and a total EC score $(\alpha=0.92)$.

IX. The Trait Emotional Intelligence Questionnaire: Short Format (TEIQue - SF; Petrides, 2009) belongs to the EI self-report mixed models. It consists of 30 items and uses a 7-point scale. This questionnaire assesses four constructs: well-being, selfcontrol, emotionality, and sociability. The internal consistency of the scale was good $(\alpha=0.881)$.

\section{RESULTS}

Emotional intelligence was measured with nine different questionnaires across the 12 selected articles. In addition, these 


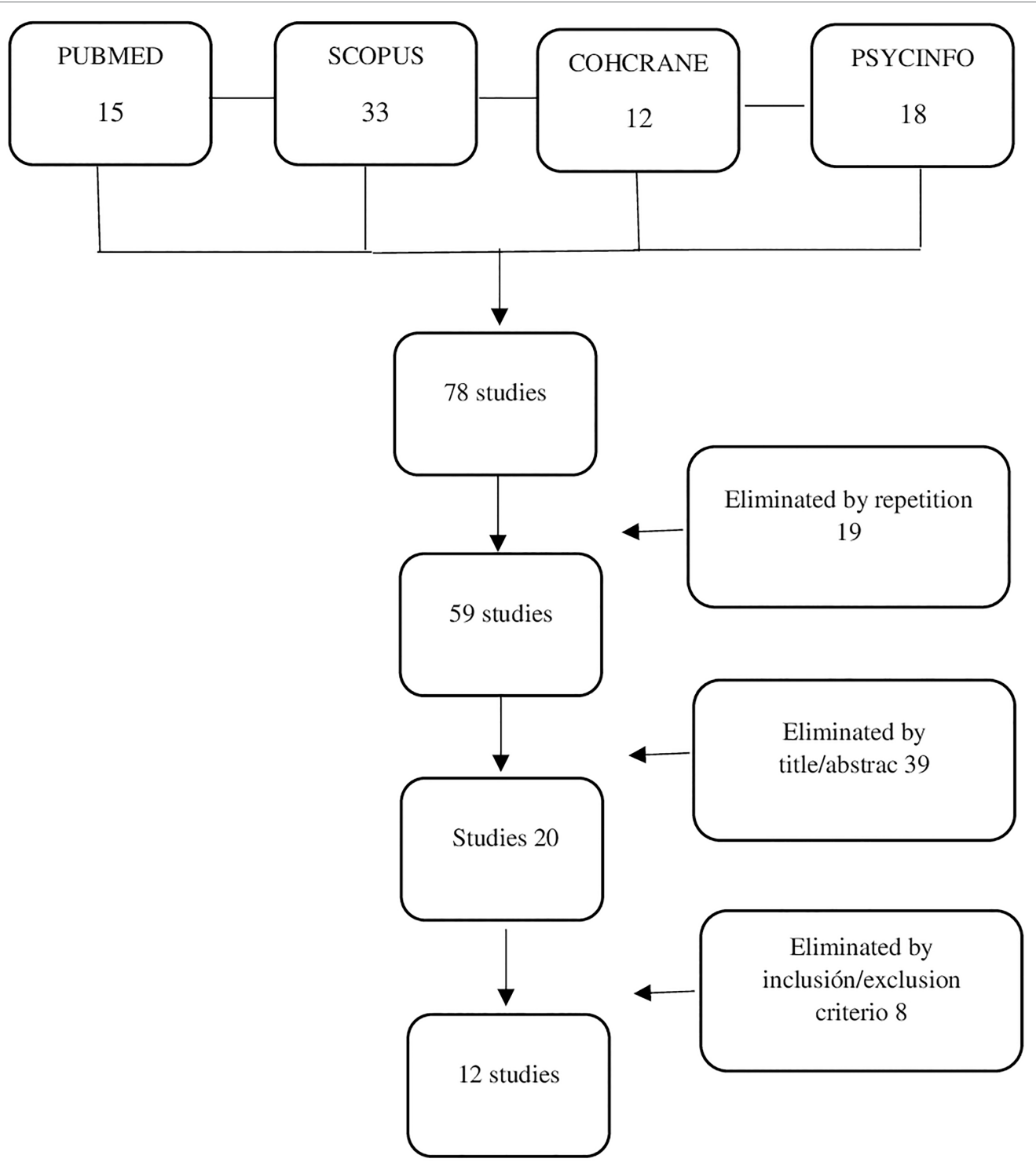

FIGURE 1 | Prisma flow diagram for the selection of the literature included in this study.

instruments were associated with different variables related to diabetes, such as $\mathrm{HbA1c}$, distress, and well-being. Given the variability in the studies, the results are divided into four main sections. The first section focuses on results concerning the relationship between EI and $\mathrm{HbA1c}$. The second presents studies that evaluate how EI training affects biological and psychological diabetes variables. Third, we describe those articles that compare EI between persons with diabetes and without diabetes, and finally, we present those results that relate EI with measures of psychological adjustment and well-being that have not previously been described.

\section{El and HbA1c}

One of the main findings of this review concerns the relationship between EI and HbAlc level. HbAlc is an indicator of mean blood glucose over the past 2-3 months and is highly sensitive to changes in blood glucose levels (Kyngäs, 2000). It is the most common and widely acceptable indicator of long-term glycemic balance (Sato, 2014). Higher levels of HbA1c indicate inadequate glycemic control. We found six studies that directly evaluated the association between EI and HbA1c (Table 2). In adults, three studies found a negative association between EI and HbA1c (Coccaro et al., 2016; Zysberg et al., 2017; Ruiz-Aranda et al., 2018). This means that higher levels of EI were related to a lower level of HbAlc. Of these three studies, two were conducted with people diagnosed with Type 1 diabetes (Zysberg et al., 2017; Ruiz-Aranda et al., 2018).

Regarding the adolescent population, two studies were found. Zysberg et al. (2013) analyzed how the parent's EI was related to the HbAlc levels of their offspring, and they found a negative correlation between both variables. That is, the higher the parent's EI, the lower the offspring's HbAlc. The study by 
TABLE 1 | Quality assessment of the included studies using the Mixed Methods Appraisal Tool (MMAT).

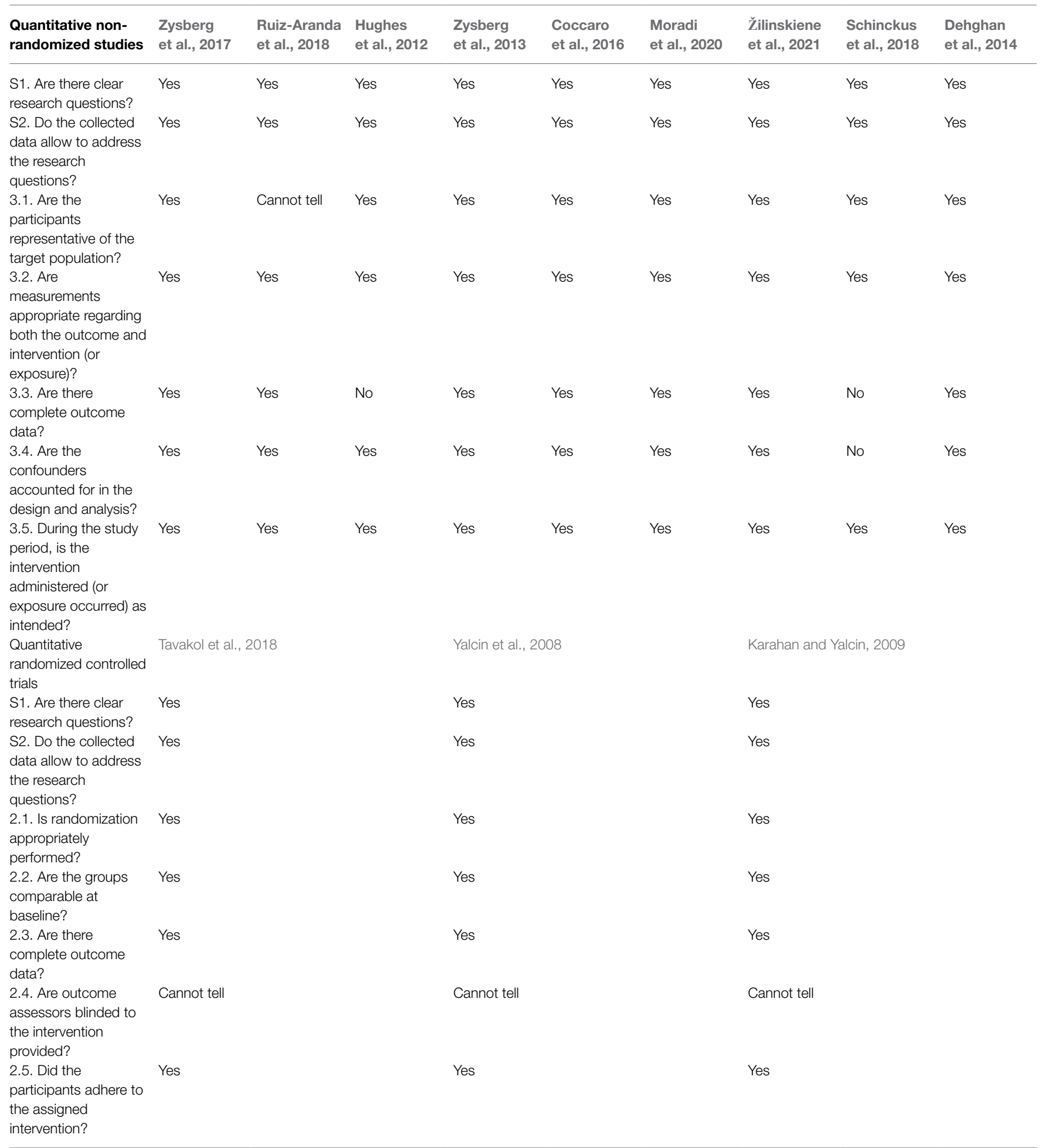

Hughes et al. (2012) also showed a negative relationship between the EI of young people and their HbAlc. Specifically, EI uniquely predicted variance in metabolic control above other diabetes-specific constructs measured in the study, such as self-control, self-efficacy, or adherence.
Finally, in a sample of 134 children and in contrast to previous results, Žilinskiene et al. (2021) found that a higher EI perception of mothers was related to poorer metabolic control in their children; that is, the ability of mothers to understand and regulate their own emotions, understand the 
TABLE 2 | Studies analyzing the relationship between emotional intelligence (EI) and HbA1c levels.

\begin{tabular}{|c|c|c|c|c|c|c|}
\hline Study & $\begin{array}{l}\text { Design and } \\
\text { objectives }\end{array}$ & Sample & Type of diabetes & El Scale & Outcome measures & Results \\
\hline $\begin{array}{l}\text { Zysberg et al., } \\
2017 \\
\text { Israel }\end{array}$ & $\begin{array}{l}\text { Cross-sectional study } \\
\text { To evaluate the } \\
\text { hypothesis that El will } \\
\text { show negative } \\
\text { associations with } \\
\text { blood glucose and } \\
\text { HbA1c level }\end{array}$ & $\begin{array}{l}78 \text { young adults. } \\
61.5 \% \text { females (mean } \\
\text { age } \\
31.89 \pm 9.97 \text { years) } \\
\text { No psychological or } \\
\text { medical intervention } \\
\text { described }\end{array}$ & Type 1 diabetes & $\begin{array}{l}\text { The audio-visual test } \\
\text { of emotional } \\
\text { intelligence (AVEI) } \\
\text { Performance-based } \\
\text { ability model } \\
\text { Mean }=17.87 \pm 2.90\end{array}$ & $\begin{array}{l}\text { Blood levels of sugar/ } \\
\text { glucose during the last } \\
\text { day } \\
\text { HbA1c levels }\end{array}$ & $\begin{array}{l}\text { A negative association } \\
\text { between El and HbA1c } \\
\text { and marginal results in } \\
\text { the same direction with } \\
\text { blood sugar levels }\end{array}$ \\
\hline $\begin{array}{l}\text { Ruiz-Aranda et al., } \\
2018 \\
\text { Israel }\end{array}$ & $\begin{array}{l}\text { Cross-sectional study } \\
\text { To examine the } \\
\text { relationship between } \\
\text { El and } \mathrm{HbA} 1 \mathrm{c} \text { levels in } \\
\text { a sample of patients } \\
\text { with Type } 1 \text { diabetes }\end{array}$ & $\begin{array}{l}85 \text { adults. } 62 \% \\
\text { females (mean age } \\
31 \pm 9.97 \text { years) } \\
\text { No psychological or } \\
\text { medical intervention } \\
\text { described }\end{array}$ & Type 1 diabetes & $\begin{array}{l}\text { The AVEl } \\
\text { Performance-based } \\
\text { ability model } \\
\text { Mean }=17.87 \pm 2.90\end{array}$ & HbA1c level & $\begin{array}{l}\text { El showed a negative } \\
\text { association with } \mathrm{HbA} 1 \mathrm{c}\end{array}$ \\
\hline $\begin{array}{l}\text { Hughes et al., } \\
2012 \\
\text { United States }\end{array}$ & $\begin{array}{l}\text { Cross-sectional study } \\
\text { To examine whether } \\
\text { emotional processing, } \\
\text { self-control and the } \\
\text { interaction between } \\
\text { these variables } \\
\text { predicted HbA1c for } \\
\text { adolescents with Type } \\
1 \text { diabetes in addition } \\
\text { to diabetes-specific } \\
\text { constructs }\end{array}$ & $\begin{array}{l}137 \text { adolescents. } 54 \% \\
\text { females (mean age } \\
13.48 \pm 1.51 \text { years) } \\
\text { Approximately half } \\
\text { (63\%) of the } \\
\text { adolescents were on } \\
\text { an insulin pump, with } \\
\text { the remainder } \\
\text { prescribed MDI }\end{array}$ & Type 1 diabetes & $\begin{array}{l}\text { The Emotional } \\
\text { Approach Coping } \\
\text { Scale. } \\
\text { Self-report ability } \\
\text { model } \\
\text { Mean }=11.81 \pm 3.02\end{array}$ & $\begin{array}{l}\text { HbA1c level } \\
\text { Self-control } \\
\text { Self-control scale } \\
\text { (Finkenauer et al., } \\
2005 \text { ) }\end{array}$ & $\begin{array}{l}\text { El in interaction with } \\
\text { self-control is } \\
\text { negatively related to } \\
\mathrm{HbA1c}\end{array}$ \\
\hline $\begin{array}{l}\text { Zysberg et al., } \\
2013 \\
\text { Israel }\end{array}$ & $\begin{array}{l}\text { Cross-sectional study } \\
\text { To evaluate the } \\
\text { hypothesis that } \\
\text { parents' emotional } \\
\text { intelligence is } \\
\text { associated with their } \\
\text { children's Type } \\
\text { I diabetes }\end{array}$ & $\begin{array}{l}81 \text { parents. } 54.3 \% \\
\text { females (mean age } \\
41.12 \pm 6.90 \text { years). } \\
\text { The mean age of the } \\
\text { children was } \\
9.9 \pm 3.41 \text { years } \\
\text { No psychological or } \\
\text { medical intervention } \\
\text { described }\end{array}$ & Type 1 diabetes & $\begin{array}{l}\text { The AVEI } \\
\text { Performance-based } \\
\text { ability model } \\
\text { Mean }=14.33 \pm 3.46 \\
\text { The Schutte Self- } \\
\text { Report Emotional } \\
\text { Intelligence Test (The } \\
\text { SEIS) } \\
\text { Self-report ability } \\
\text { model } \\
\text { Mean }=2.00 \pm 0.44\end{array}$ & HbA1c level & $\begin{array}{l}\text { A negative relationship } \\
\text { was found between El } \\
\text { of parents and the } \\
\mathrm{HbA} 1 \mathrm{c} \text { of their children }\end{array}$ \\
\hline $\begin{array}{l}\text { Coccaro et al., } \\
2016 \\
\text { United States }\end{array}$ & $\begin{array}{l}\text { Cross-sectional study } \\
\text { To investigate the } \\
\text { relationship between } \\
\text { measures of emotional } \\
\text { regulation and El and } \\
\text { HbA1c levels in adult } \\
\text { patients with Type } 2 \\
\text { diabetes }\end{array}$ & $\begin{array}{l}100 \text { adults. } 55 \% \\
\text { females (mean age } \\
59 \pm 13 \text { years) } \\
\text { No psychological or } \\
\text { medical intervention } \\
\text { described }\end{array}$ & Type 2 diabetes & $\begin{array}{l}\text { Trait Meta-Mood } \\
\text { (TMMS) } \\
\text { Self-report ability } \\
\text { model } \\
\text { Mean }=78.8 \pm 11.0\end{array}$ & HbA1c level & $\begin{array}{l}\text { El showed a negative } \\
\text { association with } \mathrm{HbA1c}\end{array}$ \\
\hline $\begin{array}{l}\text { Žlinskiene et al., } \\
2021 \\
\text { Lithuania }\end{array}$ & $\begin{array}{l}\text { Cross-sectional study } \\
\text { To investigate the } \\
\text { association between } \\
\text { mothers' El and Type } \\
\text { I diabetes disease } \\
\text { management in their } \\
\text { children }\end{array}$ & $\begin{array}{l}134 \text { mothers (mean } \\
\text { age } \\
37.83 \pm 4.37 \text { years) } \\
134 \text { children } 51.5 \% \\
\text { female (mean age } \\
9.26 \pm 2.03 \text { years) } \\
\text { No psychological or } \\
\text { medical intervention } \\
\text { described }\end{array}$ & Type 1 diabetes & $\begin{array}{l}\text { the short version of } \\
\text { El-DARL } \\
\text { Self-report ability } \\
\text { model }\end{array}$ & HbA1c level & $\begin{array}{l}\text { An increase in scores } \\
\text { of the El scales and } \\
\text { subscales of mothers } \\
\text { increases the likelihood } \\
\text { of deterioration in } \\
\text { T1DM management of } \\
\text { their children }\end{array}$ \\
\hline
\end{tabular}

causality of one's own emotions, and transform one's negative emotions into positive emotions did not facilitate the management of diabetes in their offspring.

In summary, in five out of six studies, higher levels of EI were related to better $\mathrm{HbAlc}$. In the case of adults, they included individuals with Type 1 and 2 diabetics. Finally, regarding the effect of parental EI on the HbAlc of their offspring, EI appears to be beneficial for the glycemic control of an adolescent sample, while, contrary to expectations, counterproductive in a sample of children. 


\section{El Training and Diabetes}

Three studies found a link between EI training and quality of life, well-being, anxiety, and $\mathrm{HbAlc}$ in samples of adults with Type 2 diabetes (Table 3). Tavakol et al. (2018) showed that the application of a self-care EI program improved the HbAlc levels of the participants, while Yalcin et al. (2008) showed that EI training improved quality of life and well-being in persons with diabetes and that these improvements persisted over time. Finally, Karahan and Yalcin (2009) evaluated the effect of EI training on the emotional burnout, anxiety, and $\mathrm{HbA1c}$ levels of persons with diabetes. The authors found that the program positively affected all these parameters compared to a control group of people with diabetes.

Taken together, these studies showed the positive effect of EI training in improving biological and psychological factors in people with Type 2 diabetes.

\section{Differences Between People With Diabetes and Without Diabetes}

Two studies have focused on comparing EI between persons with diabetes and without diabetes (Table 4). Schinckus et al. (2018) analyzed whether the levels of EI of people with diabetes (Type 1 and 2 indistinguishable) differed from those without diabetes. The results showed that the persons with diabetes in the study had lower intrapersonal and interpersonal EI, which resulted in a lower global emotional intelligence score than that of people without diabetes. However, when matching both groups in terms of gender, age, and educational level, the differences between the groups disappeared. Moradi et al. (2020) compared the EI and quality of life of elderly with diabetes (Type 1 and 2 indistinguishable) and without diabetes. The results showed no statistically significant differences in EI and quality of life between persons with diabetes and without diabetes.

According to the two studies described, there were no differences between the population with diabetes (Type 1 and 2 indistinguishable) and without diabetes.

\section{Emotional Intelligence and Psychological Adjustment and Well-Being}

Given the heterogeneity of the variables included in the studies selected for the review, the last section focused on the results of studies that explored the link between EI and other variables related to lifestyle of people with diabetes not previously mentioned (Table 5). Specifically, the results were divided into four sections: the relationship between EI and anxiety and burnout, EI and diabetes-related distress, EI and quality of life and well-being, and, finally, EI and marital satisfaction.

\section{Anxiety and Burnout}

One study found a linked between EI and anxiety and burnout in adults with Type 2 diabetes. Karahan and Yalcin (2009) indicated that there was a negative relationship between these two variables; that is, the higher the EI, the lower the emotional burnout and anxiety.

\section{Diabetes-Related Distress}

One study was included in this section. Schinckus et al. (2018) showed that in adults with diabetes (Type 1 and 2 indistinguishable), diabetes-related distress acted as a mediator between EI and diabetes self-management. In addition, they found that EI reduced diabetes-related distress and that this improves self-management of the disease. This means that the higher the EI, the lesser the anxiety related to diabetes, which influences the implementation of more self-management behaviors.

\section{Quality of Life and Well-Being}

One study found a link between the EI and quality of life in adults with Type 2 diabetes. Yalcin et al. (2008) demonstrated a positive relationship between EI and quality of life; a higher EI level was related to a better quality of life and general well-being of people with diabetes.

\section{Marital Satisfaction}

Finally, marital satisfaction was a further variable analyzed in adults with Type 2 diabetes. Dehghan et al. (2014) showed that marital satisfaction was positively related to EI level; that is, people with diabetes who had a higher level of EI showed greater satisfaction with their relationship.

\section{DISCUSSION}

The present systematic review has focused on analyzing the relationship between EI and various biological and psychological variables in people with Type 1 and Type 2 diabetes to clarify the state of the art within the field and suggest future directions for research and intervention. We hypothesized that higher levels of EI would be related to better diabetes management and fewer emotional problems in this population. Given the variety of studies found in the literature search, we divided the results in four main sections.

In the first section, we included those studies in which the relationship between EI and HbAlc was analyzed. This was one of the main objectives of the review since HbAlc is a standard indicator of glycemic control. The results in both adults and adolescents showed that higher EI scores were related to lower HbA1c levels in people with Type 1 and 2 diabetes. This negative relationship was also found between the EI of the parents and the HbAlc of their adolescent offspring, except for a study in children, which found the opposite (and unexpected) result: a positive relationship between maternal EI and the HbAlc of their children. According to the authors, this result may be due to the use of a self-report which reflects the mothers' subjective attitude toward their EI ability and also the fact that caregivers use ineffective cognitive strategies to regulate their emotions; that is, mothers may try to understand and control their emotions, but coping strategies may not be appropriate for responding to the diabetes challenges of their offspring (Cabello et al., 2021). From this, we can conclude that EI seems to play a relevant role in glycemic control. Diabetes (primarily Type 1 diabetes) has been related to anxiety, depression, and anxiety (Anderson et al., 2001; Grigsby et al., 2002; Nicolucci et al., 2013) which makes management of the disease more difficult. The results of this section might seem logical given that EI provides people with the resources required to manage their emotions and adequately 
TABLE 3 | Studies analyzing El training in people with diabetes.

\begin{tabular}{|c|c|c|c|c|c|c|}
\hline Study & $\begin{array}{l}\text { Design and } \\
\text { objectives }\end{array}$ & Sample & Type of diabetes & EI Scale & Outcome measures & Results \\
\hline \multirow[t]{5}{*}{$\begin{array}{l}\text { Tavakol et al., } 2018 \\
\text { Iran }\end{array}$} & $\begin{array}{l}\text { Randomized } \\
\text { Controlled Trial }\end{array}$ & $\begin{array}{l}42 \text { adults. } 73.8 \% \\
\text { females. }\end{array}$ & \multirow[t]{5}{*}{ Type 2 diabetes } & $\begin{array}{l}\text { The BarOn } \\
\text { questionnaire (EQ-I) }\end{array}$ & \multirow[t]{5}{*}{$\mathrm{HbA1c}$ level } & \multirow{5}{*}{$\begin{array}{l}\text { Self-care education } \\
\text { improved HbA1c and } \\
\text { El levels }\end{array}$} \\
\hline & \multirow{4}{*}{$\begin{array}{l}\text { To investigate the } \\
\text { effect of self-care } \\
\text { education on El and } \\
\text { HbA1c in patients } \\
\text { with Type } 2 \text { diabetes }\end{array}$} & \multirow{2}{*}{$\begin{array}{l}\text { Control group } n=21 \\
\text { (mean age } \\
45.42 \pm 7.71 \text { years). }\end{array}$} & & $\begin{array}{l}\text { Self-report mixed } \\
\text { model }\end{array}$ & & \\
\hline & & & & $\begin{array}{l}\text { Intervention before: } \\
\text { Mean }=65.09+6.49\end{array}$ & & \\
\hline & & \multirow[t]{2}{*}{$\begin{array}{l}\text { No medical } \\
\text { intervention described }\end{array}$} & & $\begin{array}{l}\text { Intervention after: } \\
\text { Mean }=70.95 \pm 6.92\end{array}$ & & \\
\hline & & & & $\begin{array}{l}\text { Control after: } \\
\text { Mean }=64.38 \pm 7.09\end{array}$ & & \\
\hline \multirow{6}{*}{$\begin{array}{l}\text { Yalcin et al., } 2008 \\
\text { Turkey }\end{array}$} & \multirow{6}{*}{$\begin{array}{l}\text { Randomized } \\
\text { Controlled Trial with } \\
\text { 1st and 2nd follow- } \\
\text { ups. } \\
\text { To investigate the } \\
\text { effect of an El } \\
\text { program on the } \\
\text { health-related quality } \\
\text { of life and well-being } \\
\text { of individuals with } \\
\text { Type } 2 \text { diabetes }\end{array}$} & $\begin{array}{l}\text { Study group } n=18 \\
\text { (mean age } \\
54.33 \pm 7.34 \text { years) }\end{array}$ & \multirow{6}{*}{ Type 2 diabetes } & Intervention before: & \multirow{2}{*}{$\begin{array}{l}\text { Well-Being } \\
\text { Questionnaire (WHO- } \\
\text { WBQ-22; Savli and } \\
\text { Sevinc, 2005) }\end{array}$} & \multirow{6}{*}{$\begin{array}{l}\text { El training improved } \\
\text { quality of life and well- } \\
\text { being in persons with } \\
\text { diabetes over time }\end{array}$} \\
\hline & & \multirow{3}{*}{$\begin{array}{l}\text { Control group } n=18 \\
\text { (mean age } \\
51.17 \pm 5.81 \text { years) }\end{array}$} & & Mean $=97.77 \pm 8.98$ & & \\
\hline & & & & Control before: & Quality of Life & \\
\hline & & & & Mean $=98.38 \pm 8.89$ & \multirow{3}{*}{$\begin{array}{l}\text { WHO-Quality of Life } \\
\text { (WHOQOL-Bref; } \\
\text { Skevington et al., } \\
\text { 2004) }\end{array}$} & \\
\hline & & \multirow[t]{2}{*}{$\begin{array}{l}\text { No medical } \\
\text { intervention described }\end{array}$} & & $\begin{array}{l}\text { Intervention after: } \\
\text { Mean }=124.27 \pm 5.64\end{array}$ & & \\
\hline & & & & $\begin{array}{l}\text { Control after: } \\
\text { Mean }=98.88 \pm 9.31\end{array}$ & & \\
\hline \multirow{2}{*}{$\begin{array}{l}\text { Karahan and Yalcin, } \\
2009\end{array}$} & \multirow{4}{*}{$\begin{array}{l}\text { Randomized } \\
\text { Controlled Trial with } \\
\text { 1st and 2nd follow- } \\
\text { ups. } \\
\text { To investigate the } \\
\text { effects of an "El Skills } \\
\text { Training Program" on } \\
\text { anxiety levels, } \\
\text { burnout, and HbA1c } \\
\text { in Type } 2 \text { diabetes } \\
\text { mellitus patients }\end{array}$} & \multirow{2}{*}{$\begin{array}{l}36 \text { adults. } 50 \% \\
\text { females }\end{array}$} & \multirow[t]{4}{*}{ Type 2 diabetes } & The BarOn & HbA1c level & \multirow{4}{*}{$\begin{array}{l}\text { El program improved } \\
\text { emotional burnout, } \\
\text { anxiety and } \mathrm{HbA1C}\end{array}$} \\
\hline & & & & questionnaire (EQ-I) & Anxiety & \\
\hline \multirow[t]{2}{*}{ Turkey } & & $\begin{array}{l}\text { Training group } n=18 \\
\text { (mean age } \\
53.06 \pm 4.43 \text { years) }\end{array}$ & & $\begin{array}{l}\text { Self-report mixed } \\
\text { model }\end{array}$ & $\begin{array}{l}\text { Beck Anxiety } \\
\text { Inventory (BAl; Beck } \\
\text { et al., 1988) }\end{array}$ & \\
\hline & & $\begin{array}{l}\text { No medical } \\
\text { intervention described }\end{array}$ & & $\begin{array}{l}\text { Control after: } \\
\text { Mean }=97.0 \pm 6.1\end{array}$ & & \\
\hline
\end{tabular}

face the challenges imposed, in this case, by the disease (Gratz and Roemer, 2004). In addition, these findings are consistent with the previous literature that offers evidence on the relationship between EI and physical and mental health (Martins et al., 2010; Fernández-Abascal and Martín-Díaz, 2015).

The second section included those studies evaluating the effect of EI training on people with Type 2 diabetes. The objective was to test whether EI training could improve various life aspects of people with diabetes, such as quality of life, anxiety, or glycemic control. The three studies showed that training in EI could improve all these variables compared to the control group of people with diabetes. Therefore, it is essential to note that training in EI can be a way to manage not only glycemic control but other psychological factors associated with the disease. The benefits of EI training have been found in the population with diabetes and healthy adults (Hodzic et al., 2018) and adolescents (RuizAranda et al., 2012). These studies showed EI training to be a plausible predictor of health by reducing risk factors such as anxiety, social stress, depression, or somatization and that the results can persist over time. The literature shows that EI dimensions can be better predictors of mental health than physical health (Fernández-Abascal and Martín-Díaz, 2015).

In the third section, EI levels were compared between people with Type 2 diabetes and a healthy population sample. The two studies showed that there were no statistically significant differences in EI between persons with diabetes and without diabetes. There is, however, no reason to expect individual differences as a consequence of the disease. Instead, we proposed that there might be individual differences in diabetes management according to EI levels, as shown in the first section. However, future lines of investigation should aim to analyze these results in people with Type 1 diabetes together with the employment of other EI models.

Finally, we included those studies in which EI was related to different variables of psychological adjustment and well-being 
TABLE 4 | Studies analyzing differences between people with diabetes and without diabetes.

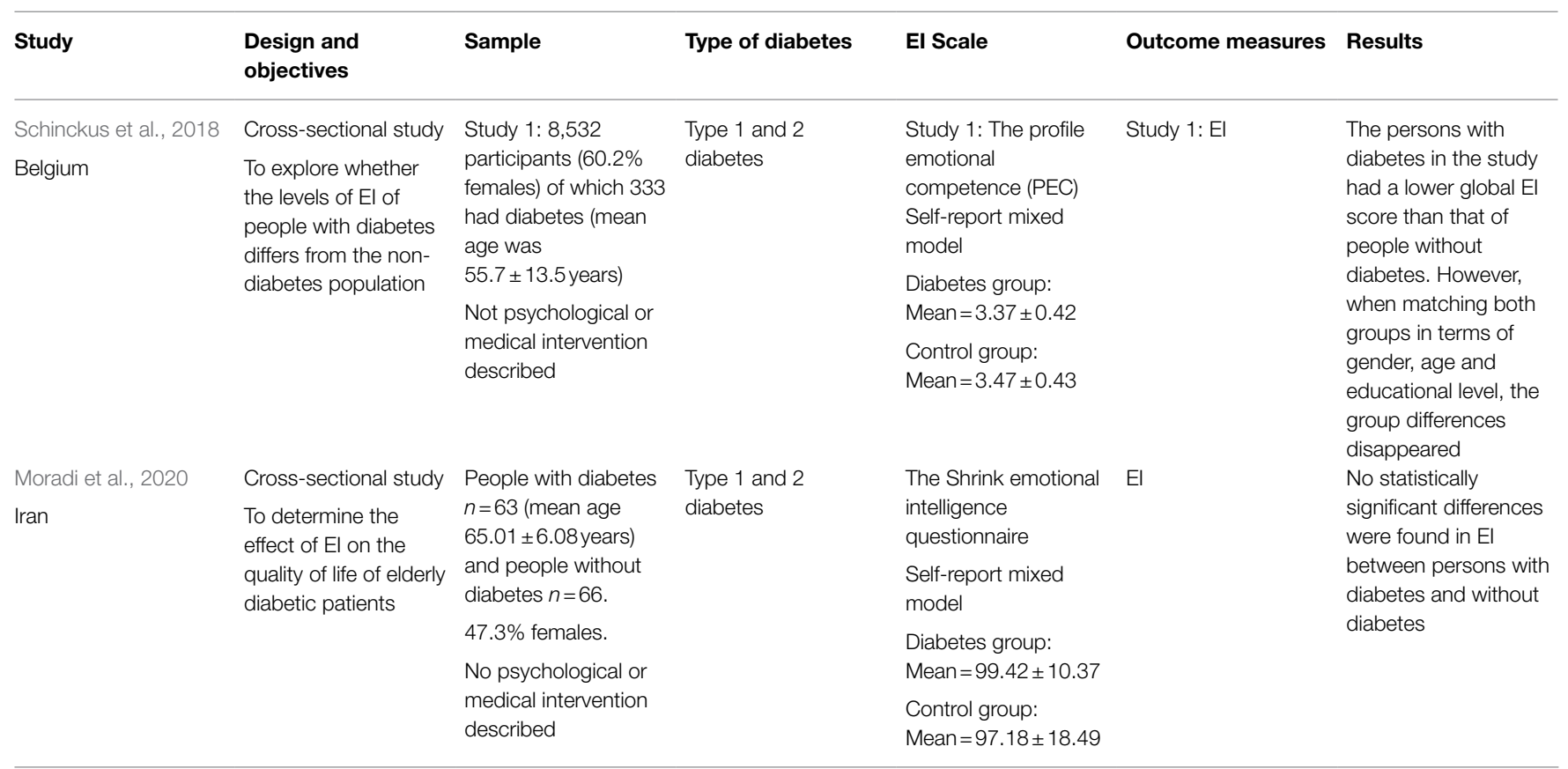

and did not meet the criteria for the previous section. The results showed that EI was negatively related to diabetes-related distress, anxiety, and burnout and positively related to quality of life, well-being, and marital satisfaction. These results are consistent with the existing literature, which supports the hypothesis that emotional abilities are an essential factor for psychological adjustment that can mitigate both anxiety and depression in adolescents (Fernandez-Berrocal et al., 2006) and adults and improve their quality of life (Sánchez-Álvarez et al., 2016).

Taking together, the results of this review offer a starting point for a theoretical and practical understanding of the role played by EI in the management of diabetes. Specifically, in light of the studies shown, EI could be a protective factor for biological and psychological variables such as glycemic control, anxiety, and diabetes-related distress. Future investigations should also evaluate the role of EI as a mediator (and not just a mechanism) between the emotional state of individuals with Type 1 and 2 diabetes and biological outcomes such as HbAlc. More importantly, EI training seems to benefit both glycemic control and the psychological dimension of the patients. These results suggest that people with diabetes, that is, Type 2, will benefit from training in EI to maximize the strategies needed to deal with the disease on a daily basis.

Despite these preliminary conclusions, it is essential to highlight certain limitations that open possible future lines of investigation. First, relatively few articles have been published that study the role of EI in people with diabetes, since we found a total of 12. This implies that this research area is still emerging. Second, regarding the EI conceptualization employed in the different studies described, three instruments belonged to the performance-based ability models, three to self-report ability models, and seven to the self-report mixed models. It is crucial to consider which model is used to measure EI since, as previously shown, there is little correlation between them
(Goldenberg et al., 2006), and they are not based on the same variables. Thus, the theoretical and clinical implications of the findings could differ according to the model employed. The model that has received the most empirical support is the performance-based ability model (Mayer et al., 2016), which was used in only three of the studies included in this review. In addition, the instrument based on the performance-based ability model only evaluates one of the four branches of the model (emotion perception), thus missing important information regarding the facilitating, understanding, and regulating EI branches. Future investigations should aim to confirm the results using instruments that cover all of the performancebased ability branches such as the MSCEIT (Mayer et al., 2002).

Thirdly, despite being different diseases, some studies do not differentiate between Type 1 and Type 2 diabetes. Both should be considered separately due to the different life implications of having one type of diabetes or another (Wong et al., 2020). Most studies included in the review have focused on Type 2, which usually appears in adulthood. In contrast, Type 1 diabetes frequently arises in childhood and adolescence. Adolescence is a developmental stage with which diabetes (as a chronic disease) interacts more negatively because the adolescent's self-image is still developing. At this stage, interpersonal relationships become more important and a particular source of stress (Chamorro et al., 2002). In addition, the treatment of Type 1 diabetes adds a stressful condition due to daily blood glucose control, insulin dose adjustment, and the coping and management of hypo- and hyperglycemia, all of which disrupt the daily lives of people with diabetes (Ortiz Parada, 2006). Therefore, future research should analyze how EI improves lifestyles and reduce sources of stress in people with Type 1 diabetes, particularly during this developmental stage. Moreover, and considering the results of 
TABLE 5 | Studies analyzing the relationship between El and psychological adjustment and well-being.

\begin{tabular}{|c|c|c|c|c|c|c|}
\hline Study & Design and objectives & Sample & Type of diabetes & EI Scale & Outcome measures & Results \\
\hline \multirow{7}{*}{$\begin{array}{l}\text { Karahan and Yalcin, } 2009 \\
\text { Turkey }\end{array}$} & \multirow{2}{*}{$\begin{array}{l}\text { Randomized Controlled Trial } \\
\text { and Cross-sectional study }\end{array}$} & 36 adults. $50 \%$ females & \multirow[t]{7}{*}{ Type 2 diabetes } & The BarOn questionnaire & Anxiety & \multirow{7}{*}{$\begin{array}{l}\text { The higher the El, the lower } \\
\text { the emotional burnout and } \\
\text { anxiety }\end{array}$} \\
\hline & & \multirow{2}{*}{$\begin{array}{l}\text { Training group } n=18 \text { (mean } \\
\text { age } 53.06 \pm 4.43 \text { years) }\end{array}$} & & $\begin{array}{l}(E Q-1) \\
\text { Self-renort mixed medel }\end{array}$ & \multirow{2}{*}{$\begin{array}{l}\text { Beck Anxiety Inventory (BAl; } \\
\text { Beck et al., 1988) }\end{array}$} & \\
\hline & \multirow{5}{*}{$\begin{array}{l}\text { To investigate the } \\
\text { relationship between El and } \\
\text { anxiety levels and burnout in } \\
\text { Type } 2 \text { diabetes patients }\end{array}$} & & & Intenention hefore. & & \\
\hline & & $\begin{array}{l}\text { Control group } n=18 \text { (mean } \\
\text { age } 52.22 \pm 5.2 \text { years) }\end{array}$ & & Mean $=97.0 \pm 6.3$ & Burnout & \\
\hline & & \multirow[t]{3}{*}{$\begin{array}{l}\text { No medical intervention } \\
\text { described }\end{array}$} & & $\begin{array}{l}\text { Control before: } \\
\text { Mean }=96.7 \pm 6.0\end{array}$ & \multirow{2}{*}{$\begin{array}{l}\text { Maslach Burnout Inventory } \\
\text { (MBI; Maslach and Jackson, } \\
\text { 1981) }\end{array}$} & \\
\hline & & & & $\begin{array}{l}\text { Intervention after: } \\
\text { Mean }=127.1 \pm 6.1\end{array}$ & & \\
\hline & & & & $\begin{array}{l}\text { Control after: } \\
\text { Mean }=97.0 \pm 6.1\end{array}$ & & \\
\hline Schinckus et al., 2018 & Cross-sectional study & \multirow{2}{*}{$\begin{array}{l}\text { Study 2: } 146 \text { adults. } 80.5 \% \\
\text { females (mean age was } \\
40 \pm 14 \text { years) }\end{array}$} & \multirow[t]{5}{*}{ Type 1 and 2 diabetes } & Study 2: The Trait Emotional & \multirow{2}{*}{$\begin{array}{l}\text { Study 2: The Diabetes Self- } \\
\text { Management }\end{array}$} & \multirow{5}{*}{$\begin{array}{l}\text { Diabetes-related distress } \\
\text { acted as a mediator between } \\
\text { El and diabetes self- } \\
\text { management. Furthermore, } \\
\text { El reduced diabetes-related } \\
\text { distress, which improves } \\
\text { self-management of the } \\
\text { disease }\end{array}$} \\
\hline \multirow[t]{4}{*}{ Belgium } & \multirow{4}{*}{$\begin{array}{l}\text { To Investigate if El reduces } \\
\text { diabetes-related distress } \\
\text { and increases self- } \\
\text { management behaviors and } \\
\text { investigate if diabetes- } \\
\text { related distress mediates the } \\
\text { relationship between trait EI } \\
\text { and diabetes self- } \\
\text { management behaviors }\end{array}$} & & & $\begin{array}{l}\text { Intelligence Questionnaire } \\
\text { (TEIQue-SF) }\end{array}$ & & \\
\hline & & \multirow{3}{*}{$\begin{array}{l}\text { Diabetes was treated mainly } \\
\text { by insulin injections only } \\
(61 \%) \text { or combined with oral } \\
\text { medication (14.4\%); } 10.3 \% \\
\text { took oral medication without } \\
\text { insulin and } 14.4 \% \text { had no } \\
\text { medication for their diabetes } \\
\text { but tried to reach/maintain a } \\
\text { healthy lifestyle }\end{array}$} & & Self-report mixed model & \multirow{3}{*}{$\begin{array}{l}\text { Diabetes Self-Management } \\
\text { Questionnaire (DSMQ; } \\
\text { Schmitt et al., 2013) } \\
\text { Diabetes Distress } \\
\text { The Diabetes Distress Scale } \\
\text { (DDS; Polonsky et al., 2005) }\end{array}$} & \\
\hline & & & & Mean $=4.81 \pm 0.828$ & & \\
\hline & & & & & & \\
\hline \multirow{5}{*}{$\begin{array}{l}\text { Dehghan et al., } 2014 \\
\text { Iran }\end{array}$} & \multirow{5}{*}{$\begin{array}{l}\text { Cross-sectional study } \\
\text { To assess the relationship } \\
\text { between attachment styles } \\
\text { and El and marital } \\
\text { satisfaction in patients with } \\
\text { Type } 2 \text { diabetes mellitus }\end{array}$} & \multirow{4}{*}{$\begin{array}{l}200 \text { married patients (mean } \\
\text { age } 43.92 \pm 12.46 \text { years) and } \\
200 \text { married healthy } \\
\text { individuals (mean age } \\
38.09 \pm 9.97 \text { years). Male } \\
\text { gender, } 51.0 \% \text { vs. } 50.0 \% .\end{array}$} & \multirow[t]{5}{*}{ Type 2 diabetes } & The BarOn questionnaire & & \multirow{5}{*}{$\begin{array}{l}\text { El was positively related to } \\
\text { marital satisfaction }\end{array}$} \\
\hline & & & & & \multirow{4}{*}{$\begin{array}{l}\text { The ENRICH questionnaire } \\
\text { (Fournier et al., 1983) }\end{array}$} & \\
\hline & & & & Self-report mixed model & & \\
\hline & & & & $\begin{array}{l}\text { Diabetes group: } \\
\text { Mean }=313.61 \pm 22.00\end{array}$ & & \\
\hline & & $\begin{array}{l}\text { Not psychological or } \\
\text { medical intervention } \\
\text { described }\end{array}$ & & $\begin{array}{l}\text { Control group: } \\
\text { Mean }=322.08 \pm 30.19\end{array}$ & & \\
\hline Yalcin et al., 2008 & \multirow{8}{*}{$\begin{array}{l}\text { Randomized Controlled Trial } \\
\text { and Cross-sectional study } \\
\text { To investigate the } \\
\text { relationship between El and } \\
\text { the health-related quality of } \\
\text { life and well-being of } \\
\text { individuals with Type } 2 \\
\text { diabetes }\end{array}$} & 36 adults. & \multirow[t]{8}{*}{ Type 2 diabetes } & The BarOn questionnaire & Quality of Life & \multirow{8}{*}{$\begin{array}{l}\text { Positive relationship between } \\
\text { El and quality of life }\end{array}$} \\
\hline \multirow[t]{7}{*}{ Turkey } & & \multirow{3}{*}{$\begin{array}{l}50 \% \text { females. Study group } \\
n=18 \text { (mean age } \\
54.33 \pm 7.34 \text { years) }\end{array}$} & & & \multirow{7}{*}{$\begin{array}{l}\text { WHO-Quality of Life } \\
\text { (WHOQOL-Bref; Skevington } \\
\text { et al., 2004) }\end{array}$} & \\
\hline & & & & Self-report mixed model & & \\
\hline & & & & $\begin{array}{l}\text { Intervention before: } \\
\text { Mean }=97.77 \pm 8.98\end{array}$ & & \\
\hline & & age $51.17 \pm 5.81$ years) & & Control before: & & \\
\hline & & \multirow{3}{*}{$\begin{array}{l}\text { No medical intervention } \\
\text { described }\end{array}$} & & Mean $=98.38 \pm 8.89$ & & \\
\hline & & & & $\begin{array}{l}\text { Intervention after: } \\
\text { Mean }=124.27 \pm 5.64\end{array}$ & & \\
\hline & & & & $\begin{array}{l}\text { Control after: } \\
\text { Mean }=98.88 \pm 9.31\end{array}$ & & \\
\hline
\end{tabular}


EI training in adults, we expect adolescents (who are particularly vulnerable) to benefit significantly from these interventions.

In conclusion, this review offers a starting point for proposing new research that could be beneficial for people with diabetes. At a theoretical level, the data suggest that EI could be a key protective variable for both psychological and biological adjustment in people with diabetes by supplying them with strategies for coping with the disease in daily life. Although further research is needed, the preliminary findings indicate that EI training could be an effective complementary tool for the management of diabetes in this population.

\section{DATA AVAILABILITY STATEMENT}

The original contributions presented in the study are included in the article/supplementary material, further inquiries can be directed to the corresponding author.

\section{REFERENCES}

Anderson, R. J., Freedland, K. E., Clouse, R. E., and Lustman, P. J. (2001). The prevalence of comorbid depression in adults with diabetes: a metaanalysis. Diabetes Care 24, 1069-1078. doi: 10.2337/diacare.24.6.1069

Antiniené, D., and Lekavičienè, R. (2014). Design characteristics of the short version Ei-Darl-V1 of original emotional intelligence measurement technique. Balt. J. Sport Health Sci. 1, 9-15. doi: 10.33607/BJSHS.V1I92.105

Armstrong, A. R., Galligan, R. F., and Critchley, C. R. (2011). Emotional intelligence and psychological resilience to negative life events. Pers. Individ. Dif. 51, 331-336. doi: 10.1016/j.paid.2011.03.025

Bar-On, R. (2004). The Bar-On Emotional Quotient Inventory (EQ-i): rationale, description and summary of psychometric properties. Nov. Sci. Publ. Abstr. $115-145$.

Bar-On, R. (2006). The Bar-On model of emotional-social intelligence (ESI). Psicothema 18, 13-25.

Beck, A., Epstein, N., Brown, G., and Steer, R. (1988). An inventory for measuring clinical anxiety: psychometric properties. J. Consult. Clin. Psychol. 56, 893-897. doi: 10.1037/0022-006X.56.6.893

Brasseur, S., Grégoire, J., Bourdu, R., and Mikolajczak, M. (2013). The Profile of Emotional Competence (PEC): development and validation of a selfreported measure that fits dimensions of emotional competence theory. PLoS One 8:e62635. doi: 10.1371/journal.pone.0062635

Cabello, R., Gómez-Leal, R., Gutiérrez-Cobo, M. J., Megías-Robles, A., Salovey, P., and Fernández-Berrocal, P. (2021). Ability emotional intelligence in parents and their offspring. Curr. Psychol. 1-7. doi: 10.1007/s12144-021-01617-7

Chamorro, M. J. M., Lastra Martínez, I., and Luzuriaga Tomás, C. (2002). Perfil psicosocial de niños y adolescentes con diabetes mellitus. Bol. Pediatr. $42,114-119$.

Coccaro, E. F., Drossos, T., and Phillipson, L. (2016). HbAlc levels as a function of emotional regulation and emotional intelligence in patients with type 2 diabetes. Prim. Care Diabetes 10, 334-341. doi: 10.1016/j.pcd.2016.05.006

Collins, M. M., Corcoran, P., and Perry, I. J. (2009). Anxiety and depression symptoms in patients with diabetes. Diabet. Med. 26, 153-161. doi: 10.1111/j. 1464-5491.2008.02648.x

Costa, S., Petrides, K. V., and Tillmann, T. (2014). Trait emotional intelligence and inflammatory diseases. Psychol. Health Med. 19, 180-189. doi: 10.1080/13548506.2013.802356

Dehghan, M., Hejazi, M., and Salehi, J. (2014). The relationship of attachment styles and emotional intelligence with marital satisfaction in patients with type 2 diabetes mellitus (marital satisfaction and its main determinants in diabetics). Adv. Environ. Biol. 8, 707-714.

Egede, L. E. (2004). Diabetes, major depression, and functional disability among U.S. adults. Diabetes Care 27, 421-428. doi: 10.2337/diacare.27.2.421

\section{AUTHOR CONTRIBUTIONS}

AP-F: conceptualization, data research, methodology, validation, investigation, writing - original draft preparation, and visualization. PF-B: term, conceptualization, validation, supervision, project administration, funding acquisition, and supervision. MG-C: term, conceptualization, data research, methodology, validation, writing - review and editing, visualization, and supervision. All authors contributed to the article and approved the submitted version.

\section{FUNDING}

This work was supported by the Spanish Ministry of Economy, Industry, and Competitiveness (project: PSI2017-84170-R), Junta de Andalucía (UMA18-FEDERJA-114) and CTS-575.

Fernández-Abascal, E. G., and Martín-Díaz, M. D. (2015). Dimensions of emotional intelligence related to physical and mental health and to health behaviors. Front. Psychol. 6:317. doi: 10.3389/fpsyg.2015.00317

Fernandez-Berrocal, P., Alcaide, R., Extremera, N., and Pizarro, D. (2006). The role of emotional intelligence in anxiety and depression among adolescents. Individ. Differ. Res. 4, 16-27.

Fernández-Berrocal, P., and Extremera, N. (2016). Ability emotional intelligence, depression, and well-being. Emot. Rev. 8, 311-315. doi: $10.1177 / 1754073916650494$

Finkenauer, C., Engels, R. C. M. E., and Baumeister, R. F. (2005). Parenting behaviour and adolescent behavioural and emotional problems: the role of self-control. Int. J. Behav. Dev. 29, 58-69. doi: 10.1080/01650250444000333

Fournier, D. G., Olson, D. H., and Druckman, J. (1983). "Assessing marital and premarital relationships: the PREPARE-ENRICH inventories," in Marriage and Family Assessment. ed. E. E. Filsinger (Beverly Hills: Sage Publishing), $229-250$

Gendelman, N., Wadwa, R. P., Snell-Bergeon, J. K., Bishop, F., McFann, K., Rewers, M., et al. (2009). Prevalence and correlates of depression in individuals with and without type 1 diabetes. Diabetes Care 32, 575-579. doi: 10.2337/ dc08-1835

Goldenberg, I., Matheson, K., and Mantler, J. (2006). The assessment of emotional intelligence: a comparison of performance-based and self-report methodologies. J. Pers. Assess. 86, 33-45. doi: 10.1207/s15327752jpa8601_05

Goldney, R. D., Phillips, P. J., Fisher, L. J., and Wilson, D. H. (2004). Diabetes, depression, and quality of life: a population study. Diabetes Care 27, 1066-1070. doi: $10.2337 /$ diacare.27.5.1066

Gonder-Frederick, L., Cox, D., Bobbitt, S., and Pennebaker, J. (1989). Mood changes associated with blood glucose fluctuations in insulin-dependent diabetes mellitus. Health Psychol. 8, 45-59. doi: 10.1037/0278-6133.8.1.45

Goodnick, P. (2001). Use of antidepressants in treatment of comorbid diabetes mellitus and depression as well as in diabetic neuropathy. Ann. Clin. Psychiatry 13, 31-41. doi: 10.3109/10401230109147127

Gratz, K. L., and Roemer, L. (2004). Multidimensional assessment of emotion regulation and dysregulation: development, factor structure, and initial validation of the difficulties in Emotion Regulation Scale. J. Psychopathol. Behav. Assess. 26, 41-54. doi: 10.1023/B:JOBA.0000007455.08539.94

Grigsby, A. B., Anderson, R. J., Freedland, K. E., Clouse, R. E., and Lustman, P. J. (2002). Prevalence of anxiety in adults with diabetes a systematic review. J. Psychosom. Res. 53, 1053-1060. doi: 10.1016/S0022-3999(02)00417-8

Hermanns, N., Kubiak, T., Kulzer, B., and Haak, T. (2003). Emotional changes during experimentally induced hypoglycaemia in type 1 diabetes. Biol. Psychol. 63, 15-44. doi: 10.1016/S0301-0511(03)00027-9

Hislop, A. L., Fegan, P. G., Schlaeppi, M. J., Duck, M., and Yeap, B. B. (2008). Prevalence and associations of psychological distress in young adults with type 1 diabetes. Diabet. Med. 25, 91-96. doi: 10.1111/j.1464-5491.2007.02310.x 
Hodzic, S., Scharfen, J., Ripoll, P., Holling, H., and Zenasni, F. (2018). How efficient are emotional intelligence trainings: a meta-analysis. Emot. Rev. 10, 138-148. doi: 10.1177/1754073917708613

Hong, Q. N., Fàbregues, S., Bartlett, G., Boardman, F., Cargo, M., Dagenais, P., et al. (2018). The Mixed Methods Appraisal Tool (MMAT) version 2018. Industry Canada.

Hughes, A. E., Berg, C. A., and Wiebe, D. J. (2012). Emotional processing and self-control in adolescents with type 1 diabetes. J. Pediatr. Psychol. 37, 925-934. doi: 10.1093/jpepsy/jss062

Joseph, D. L., and Newman, D. A. (2010). Emotional intelligence: an integrative meta-analysis and cascading model. J. Appl. Psychol. 95, 54-78. doi: 10.1037/ a0017286

Karahan, T. F., and Yalcin, B. M. (2009). The effects of an emotional intelligence skills training program on anxiety, burnout and glycemic control in type 2 diabetes mellitus patients. Turk. Klin. J. Med. Sci. 29, 16-24.

Killgore, W. D. S., Sonis, L. A., Rosso, I. M., and Rauch, S. L. (2016). Emotional intelligence partially mediates the association between anxiety sensitivity and anxiety symptoms1,2. Psychol. Rep. 118, 23-40. doi: 10.1177/0033294115625563

Kyngäs, H. V. I. (2000). Compliance of adolescents with chronic disease. J. Clin. Nurs. 9, 549-556. doi: 10.1046/j.1365-2702.2000.00368.x

Lin, E. H. B., Rutter, C. M., Katon, W., Heckbert, S. R., Ciechanowski, P., Oliver, M. M., et al. (2010). Depression and advanced complications of diabetes: a prospective cohort study. Diabetes Care 33, 264-269. doi: 10.2337/ dc09-1068

Martins, A., Ramalho, N., and Morin, E. (2010). A comprehensive meta-analysis of the relationship between emotional intelligence and health. Pers. Individ. Differ. 49, 554-564. doi: 10.1016/j.paid.2010.05.029

Maslach, C., and Jackson, S. E. (1981). The measurement of experienced burnout. J. Organ. Behav. 2, 99-113. doi: 10.1002/job.4030020205

Mayer, J. D., Caruso, D. R., and Salovey, P. (2016). The ability model of emotional intelligence: principles and updates. Emot. Rev. 8, 290-300. doi: $10.1177 / 1754073916639667$

Mayer, J., and Salovey, P. (1997). "What is emotional intelligence?" in Emotional Development and Emotional Intelligence: Implications for Educators. eds. P. Salovey and D. Sluyter (New York: Bassic Books), 3-31.

Mayer, J., Salovey, P., and Caruso, D. (2002). Mayer-Salovey-Caruso Emotional Intelligence Test (MSCEIT) Users Manual. Toronto: MHS.

Mikolajczak, M., Avalosse, H., Vancorenland, S., Verniest, R., Callens, M., Van Broeck, N., et al. (2015). A nationally representative study of emotional competence and health. Emotion 15, 653-667. doi:10.1037/emo0000034.

Moradi, F., Tourani, S., Ziapour, A., Abbas, J., Hematti, M., Moghadam, E. J., et al. (2020). Emotional intelligence and quality of life in elderly diabetic patients. Int. Q. Community Health Educ. 42, 15-20. doi: 10.1177/0272684X20965811

Musselman, D. L., Betan, E., Larsen, H., and Phillips, L. S. (2003). Relationship of depression to diabetes types 1 and 2: epidemiology, biology, and treatment. Biol. Psychiatry 54, 317-329. doi: 10.1016/S0006-3223(03)00569-9

Nicolucci, A., Kovacs Burns, K., Holt, R. I. G., Comaschi, M., Hermanns, N., Ishii, H., et al. (2013). Diabetes attitudes, wishes and needs second study (DAWN2 ${ }^{\mathrm{TM}}$ ): cross-national benchmarking of diabetes-related psychosocial outcomes for people with diabetes. Diabet. Med. 30, 767-777. doi: 10.1111/dme.12245

Ortiz Parada, M. (2006). Estrés, Estilo de Afrontamiento y Adherencia al Tratamiento de Adolescentes Diabéticos Tipo 1. Stress, copying style, and treatment adherence in adolescents suffering from type I diabetes. Ter. Psicol. 24, 139-148.

Park, M., Katon, W. J., and Wolf, F. M. (2013). Depression and risk of mortality in individuals with diabetes: a meta-analysis and systematic review. Gen. Hosp. Psychiatry 35, 217-225. doi: 10.1016/j.genhosppsych.2013.01.006

Petrides, K. V. (2009). "Psychometric properties of the Trait Emotional Intelligence Questionnaire (TEIQue)," in Advances in the Assessment of Emotional Intelligence. eds. C. Stough, D. H. Saklofske and J. D. Parker (Boston, MA: Springer), 85-101.

Peyrot, M., McMurry, J. F., and Kruger, D. F. (1999). A biopsychosocial model of glycemic control in diabetes: stress, coping and regimen adherence. $J$. Health Soc. Behav. 40, 141-158. doi: 10.2307/2676370

Polonsky, W., Fisher, L., Earles, J., Dudl, R., Lees, J., Mullan, J., et al. (2005). Assessing psychosocial distress in diabetes: development of the diabetes distress scale. Diabetes Care 28, 626-631. doi: 10.2337/diacare.28.3.626
Ruiz-Aranda, D., Castillo, R., Salguero, J. M., Cabello, R., Fernández-Berrocal, P., and Balluerka, N. (2012). Short- and midterm effects of emotional intelligence training on adolescent mental health. J. Adolesc. Health 51, 462-467. doi: 10.1016/j.jadohealth.2012.02.003

Ruiz-Aranda, D., Zysberg, L., García-Linares, E., Castellano-Guerrero, A. M., Martínez-Brocca, M. A., and Gutiérrez-Colosía, M. R. (2018). Emotional abilities and HbAlc levels in patients with type 1 diabetes. Psychoneuroendocrinology 93, 118-123. doi: 10.1016/j.psyneuen.2018.04.015

Saeedi, P., Petersohn, I., Salpea, P., Malanda, B., Karuranga, S., Unwin, N., et al. (2019). Global and regional diabetes prevalence estimates for 2019 and projections for 2030 and 2045: results from the international diabetes federation diabetes atlas, 9th edition. Diabetes Res. Clin. Pract. 157:107843. doi: 10.1016/j.diabres.2019.107843

Salovey, P., Mayer, J., Goldman, S., Turvey, C., and Palfai, T. (1995). "Emotional attention, clarity, and repair: exploring emotional intelligence using the Trait Meta-Mood Scale," in Emotion, Disclosure, and Health. ed. J. W. Pennebaker (American Psychological Association), 125-154.

Sánchez-Álvarez, N., Extremera, N., and Fernández-Berrocal, P. (2016). The relation between emotional intelligence and subjective well-being: a metaanalytic investigation. J. Posit. Psychol. 11, 276-285. doi: 10.1080/17439760.2015.1058968

Sapolsky, R., Romero, L., and Munck, A. (2000). How do glucocorticoids influence stress responses? Integrating permissive, suppressive, stimulatory, and preparative actions. Endocr. Rev. 21, 55-89. doi: 10.1210/edrv.21.1.0389

Sato, A. (2014). Indicators of glycemic control --hemoglobin A1c (HbA1c), glycated albumin (GA), and 1,5-anhydroglucitol (1,5-AG). Rinsho Byori 62, 45-52.

Savli, H., and Sevinc, A. (2005). The evaluation of the Turkish version of the Well-Being Questionnaire (WBQ-22) in patients with type 2 diabetes: the effects of diabetic complications. J. Endocrinol. Investig. 28, 683-691. doi: 10.1007/BF03347550

Schinckus, L., Avalosse, H., Van den Broucke, S., and Mikolajczak, M. (2018). The role of trait emotional intelligence in diabetes self-management behaviors: the mediating effect of diabetes-related distress. Pers. Individ. Differ. 131, 124-131. doi: 10.1016/j.paid.2018.03.028

Schmitt, A., Gahr, A., Hermanns, N., Kulzer, B., Huber, J., and Haak, T. (2013). The Diabetes Self-Management Questionnaire (DSMQ): development and evaluation of an instrument to assess diabetes self-care activities associated with glycaemic control. Health Qual. Life Outcomes 11:138. doi: 10.1186/1477-7525-11-138

Schutte, N. S., Malouff, J. M., Hall, L. E., Haggerty, D. J., Cooper, J. T., Golden, C. J., et al. (1998). Development and validation of a measure of emotional intelligence. Pers. Individ. Differ. 25, 167-177. doi: 10.1016/ S0191-8869(98)00001-4

Sipkoff, M. (2005). New study links diabetes, depression, and death. Drug Topics 149. Available at: https://www.drugtopics.com/view/new-study-linksdiabetes-depression-and-death (Accessed June, 2020).

Skevington, S., Lotfy, M., and O'Connell, K. (2004). The World Health Organization's WHOQOL-BREF quality of life assessment: psychometric properties and results of the international field trial. A report from the WHOQOL group. Qual. Life Res. 13, 299-310. doi: 10.1023/B:QURE.0000018486.91360.00

Smith, K. J., Béland, M., Clyde, M., Gariépy, G., Pagé, V., Badawi, G., et al. (2013). Association of diabetes with anxiety: a systematic review and metaanalysis. J. Psychosom. Res. 74, 89-99. doi: 10.1016/j.jpsychores.2012.11.013

Stanton, A. L., Kirk, S. B., Cameron, C. L., and Danoff-Burg, S. (2000). Coping through emotional approach: scale construction and validation. J. Pers. Soc. Psychol. 78, 1150-1169. doi: 10.1037/0022-3514.78.6.1150

Tavakol, S., Najafi, S. S., and Yektatalab, S. (2018). The effect of self-care education on emotional intelligence and HbAlc level in patients with type 2 diabetes mellitus: a randomized controlled clinical trial. Int. J. Community Based Nurs. Midwifery 6, 39-46. doi: 10.30476/ijcbnm.2018.40812

WHO (2020). Diabetes. Available at: https://www.who.int/news-room/fact-sheets/ detail/diabetes (Accessed June, 2020).

Wild, S., Roglic, G., Green, A., Sicree, R., and King, H. (2004). Global prevalence of diabetes: estimates for the year 2000 and projections for 2030. Diabetes Care 27, 1047-1053. doi: 10.2337/diacare.27.5.1047

Wong, J. J., Addala, A., Abujaradeh, H., Adams, R. N., Barley, R. C., Hanes, S. J., et al. (2020). Depression in context: important considerations for youth with type 1 vs type 2 diabetes. Pediatr. Diabetes 21, 135-142. doi: 10.1111/pedi.12939

Yalcin, B. M., Karahan, T. F., Ozcelik, M., and Igde, F. A. (2008). The effects of an emotional intelligence program on the quality of life and well-being 
of patients with type 2 diabetes mellitus. Diabetes Educ. 34, 1013-1024. doi: $10.1177 / 0145721708327303$

Zeidner, M., Matthews, G., and Roberts, R. D. (2012). The emotional intelligence, health, and well-being nexus: what have we learned and what have we missed? Appl. Psychol. Health Well Being 4, 1-30. doi: 10.1111/j.1758-0854.2011.01062.x

Žilinskiene, J., Šumskas, L., and Dalia, A. (2021). Paediatric type1 diabetes management and mothers' emotional intelligence interactions. Int. J. Environ. Res. Public Health 18:3117. doi: 10.3390/IJERPH18063117

Zysberg, L., Bar Yoseph, T., and Goldman, M. (2017). Emotional intelligence and glycemic management among type I diabetes patients. J. Health Psychol. 22, 158-163. doi: $10.1177 / 1359105315596373$

Zysberg, L., Lang, T., and Zisberg, A. (2013). Parents' emotional intelligence and children's type I diabetes management. J. Health Psychol. 18, 1121-1128. doi: $10.1177 / 1359105312459097$

Zysberg, L., Levy, A., and Zisberg, A. (2011). Emotional intelligence in applicant selection for care-related academic programs. J. Psychoeduc. Assess. 29, 27-38. doi: $10.1177 / 0734282910365059$
Conflict of Interest: The authors declare that the research was conducted in the absence of any commercial or financial relationships that could be construed as a potential conflict of interest.

Publisher's Note: All claims expressed in this article are solely those of the authors and do not necessarily represent those of their affiliated organizations, or those of the publisher, the editors and the reviewers. Any product that may be evaluated in this article, or claim that may be made by its manufacturer, is not guaranteed or endorsed by the publisher.

Copyright () 2021 Pérez-Fernández, Fernández-Berrocal and Gutiérrez-Cobo. This is an open-access article distributed under the terms of the Creative Commons Attribution License (CC BY). The use, distribution or reproduction in other forums is permitted, provided the original author(s) and the copyright owner(s) are credited and that the original publication in this journal is cited, in accordance with accepted academic practice. No use, distribution or reproduction is permitted which does not comply with these terms. 